\title{
Parotid Gland Lymph Node
}

National Cancer Institute

\section{Source}

National Cancer Institute. Parotid Gland Lymph Node. NCI Thesaurus. Code C33278.

A lymph node located close to, on, or within the parotid gland. 